\title{
10- Yabancı dil olarak Türkçe öğretiminde teknoloji destekli akran öğretiminin konuşma kaygısına etkisi
}

\section{Bekir İNCE}

APA: İnce, B. (2021). Yabancı dil olarak Türkçe öğretiminde teknoloji destekli akran öğretiminin konuşma kaygısına etkisi. RumeliDE Dil ve Edebiyat Araştırmaları Dergisi, (Ö10), 171-179. DOI: 10.29000/rumelide.1012525.

$\ddot{\mathbf{O z}}$

İletişimin iki temel boyutu vardır: Anlama ve anlatma. Dil konuşurları açısından her iki boyutun da farklı farklı zorlukları bulunmaktadır. Ancak bir dili yabancı dil olarak öğrenen bireyler açısından bakıldığında iki boyut içerisinde özellikle ifade etme becerilerinin belirli bir zorluk içerdiği söylenebilir. Bilhassa konuşma becerisinin öğrenciler açısından önemli bir kaygı kaynağı olduğu bilinmektedir. Bu çalışmada yabancı dil olarak Türkçe öğrenen bireylerin ana dili konuşuru olan akranları ile teknoloji destekli etkileşime girmelerinin konuşma kaygılarına etkisi araştırılmıştır. Tarama modelinde betimsel nitelikli bu çalışmada veri toplama tekniklerinden sormaca tekniği kullanılmıştır. Bu bağlamda 5'li likert ile 10 soruluk bir sormaca hazırlanmıştır. Çalışma ile Sakarya Üniversitesi TÖMER'de öğrenim gören 56 öğrenci ile Sakarya Üniversitesi Türkçe Öğretmenliği bölümünde yabancı dil olarak Türkçe dersini alan 56 Türkçe öğretmeni adayının teknoloji destekli akran öğretimi modeli ile bir araya gelmeleri sağlanarak bu modelin Türkçe öğrenen yabancıların konuşma kaygılarında nasıl bir etkisi olduğu araştırılmıştır. ${ }^{2}$ Çalışmanın sonuçları, Türkçe öğrenen yabancılarda teknoloji destekli akran öğretiminin konuşma kaygısı üzerinde olumlu etkisi olduğunu ortaya koymaktadır. Nitekim öğrenicilerin büyük çoğunluğu daha önce yoğun olarak yaşadıkları bazı konuşma kaygılarında nispi azalma olduğunu ifade etmişlerdir.

Anahtar kelimeler: Konuşma kaygısı, Yabancı dil olarak Türkçe öğretimi, Teknoloji, akran öğretimi

\section{The effect of technology supported peer teaching on speaking anxiety in teaching Turkish as a foreign language}

\begin{abstract}
Communication has two basic dimensions: understanding and telling. Both dimensions have different challenges for language speakers. However, from the point of view of individuals learning a language as a foreign language, it can be said that expressing skills in two dimensions pose a certain difficulty. It is known that speaking skill is an important source of anxiety for students. In this study, the effect of technology-supported interaction with native speakers of individuals learning Turkish as a foreign language on their speaking anxiety was investigated. Questionnaire technique, one of the data collection techniques, was used in this descriptive study in the survey model. In this context, a 10-question questionnaire was prepared with a 5-point Likert scale. With the study, 56 students
\end{abstract}

Doç. Dr., İstanbul Medeniyet Üniversitesi, Eğitim Bilimleri Fakültesi, Türkçe ve Sosyal Bilimler Bölümü, Türkçe Eğitimi ABD (İstanbul, Türkiye), bince@sakarya.edu.tr, ORCID ID: oooo-ooo1-7952-2933 [Araştırma makalesi, Makale kayıt tarihi: 27.09.2021-kabul tarihi: 20.10.2021; DOI: 10.29000/rumelide.1012525]

Söz konusu çalışma, uygulamalı bir çalışma olmakla birlikte Sakarya Üniversitesinde 2017-2018 eğitim öğretim yllında öğrenim gören Türkçe Ö̆retmenliği bölümündeki öğrenciler ile ve aynı eğitim yllındaki Sakarya TÖMER’de öğrenim gören öğrenciler ile gerçekleştiğinden ve çalışma kapsamında toplanan veriler 2020 yılı öncesine ait olduğundan etik kurul izni alınmamıştır.ULAKBİM’in görüşü de 2020 yılı öncesi toplanan veriler ve çalışmalar için bu yöndedir.

Adres | Address

RumeliDE Dil ve Edebiyat Araştırmalar Dergisi $\quad$ RumeliDE Journal of Language and Literature Studies Osmanağa Mahallesi, Mürver Çiçeği Sokak, No:14/8 $\quad$ Osmanağa Mahallesi, Mürver Çiçeği Sokak, No:14/8

Kadıköy - ISTANBUL / TURKIYE 34714 Kadıköy - ISTANBUL / TURKEY 34714 e-posta: editor@rumelide.com e-mail: editor@rumelide.com, tel: +90 505 7958124, +90 2167730616 phone: +90 505 7958124, +90 2167730616 
The effect of technology supported peer teaching on speaking anxiety in teaching Turkish as a foreign language / B. Ince (pp. 171-179)

studying at TÖMER at Sakarya University and 56 Turkish teacher candidates studying Turkish as a foreign language in the Department of Turkish Language Teaching at Sakarya University were brought together with the technology-assisted peer learning model and the effect of this model on the speaking anxiety of foreigners learning Turkish was investigated. The results of the study reveal that technology-assisted peer learning has a positive effect on speaking anxiety in foreigners learning Turkish. As a matter of fact, the majority of the learners stated that there was a relative decrease in some of the speech anxiety they had experienced intensely before.

Keywords: Speaking anxiety, Teaching Turkish as a foreign language, Technology, peer teaching

\section{Giriş}

Dil aracılı̆̆ıyla, düşüncelerini ifade etme veya bilgisini birilerine aktarma yeteneğine sahip olan insanoğlu açısından iletişim vazgeçilmez bir olgudur. Yabancı bir dili öğrenmek; yalnızca dilbilgisi kurallarını öğrenmek veya kelime bilgisi edinmekle sınırlı değildir aynı zamanda sözlü gerçekleştirilen tüm performanslarda ustalaşmak da yabancı bir dili öğrenmenin önemli amaçları arasındadır. Türkçeyi yabancı dil olarak Öğrenen öğrencilerin büyük çoğunluğunun derslerde sözlü performanslarını ortaya koyarken zorluk yaşadığı görülmektedir. Öğrenciler, sözlü performanslarında özellikle de değişik ifade yapılarının kullanımında engele takılmakta ve konuşma kaygısı yaşamaktadırlar. Ergür, yabancı dil öğrenme sürecinde kaygı ve özgüvenden kaynaklı eksikliklerin başarıyı olumsuz yönde etkilediğini dile getirmektedir (Ergün, 2004:48). Nitekim bu öğrenciler öğretmenle ya da sınıf arkadaşlarıyla konuşmakta gerçekten zorlandıkları yerlerde sözlü iletişime girmekten de korkarlar. Yabancı dil kaygısıyla ilgili çalışmalar, en çok yabancı dil sınıflarında konuşma performansının sergilendiği aşamalarda kaygının ortaya çıktığını göstermektedir (Bekleyen 2004, akt. Sallabaş 2012). Dahası yabancı dil öğreniminde kaygı düzeyi öğrencilerin dil öğrenme başarılarını da etkilemektedir (Öner ve Gedikoğlu 2007). Bu bağlamda söz, sözcük, konuşma eylemi gibi kavramlar gerek başkaları tarafından gerek sınıf içinde öğretmen tarafindan yargılanmaktan korkan yabancı dil olarak Türkçe öğrenen öğrenciler açısından risk olarak algılanan önemli kavramlardır. Öğrenciler yanlış anlaşılmaktan ya da yanlış telaffuzdan korkarlar. Aslında bu sorun yalnızca yabancı dil öğretiminde değil ana dil öğretiminde de öğrencilerin kendilerini daha iyi ifade etmelerini engeller. YTÖ sınıflarındaki bu öğrenciler bu türden bir engelle karşılaştıklarında çoğu zaman susmayı tercih ederler. Dile olan ihtiyacımızın temelinde iletişim kurmak yatar. İletişim kurmak ise en sade şekliyle kendimizi anlatmak ve karşımızdaki kişi veya kişileri anlamak olarak ifade edilebilir. Dil dersleri bu iletişim becerisinin kazanılmasında kilit rol oynar. Bu noktada akran öğretiminin kaygıyı azaltmada önemli bir rol üstlendiğini söylemek mümkündür. Akran öğretimi yöntemiyle Lisans seviyesindeki öğrenciler üzerinde yapılan çalışmalar, öğrencilerin performanslarında iyi oranda bir artış olduğunu ortaya koymaktadır (Demirci ve Şekercioğlu, 2009: 37). Şeref, akran öğretimi modelinin yabancı dil olarak Türkçe öğretiminde sosyokültürel etkileşim alanı içinde icra edilen önemli bir dil öğretim aracı olduğunu ifade etmektedir (Şeref, 2018: 150). Bu noktada Sosyal ve kültürel çevrenin bireyleri şekillendirmedeki gücünü dil öğretim sürecine katmak; dil öğretimi açısından hem öğrenicilere hem de öğreticilere büyük bir avantaj kazandırmaktadır. Öte yandan Bayrakdar ve Maltepe'de öğrenme sürecinde ve öğrenme sonrası değerlendirme sürecinde belirli ölçütleri temele alarak akranlarının ürünlerini inceleyerek onlara geri bildirim sağlamanın, öğrenciöğrenci, öğrenci-öğretici etkileşimini en üst seviyeye çıkaran bir yaklaşım olarak nitelendirilebileceğini söylemektedir (Bayrakdar ve Maltepe, 2021).

\footnotetext{
Adres | Address

RumeliDE Dil ve Edebiyat Araştırmaları Dergisi $\quad$ RumeliDE Journal of Language and Literature Studies Osmanağa Mahallesi, Mürver Çiçeği Sokak, No:14/8 $\quad$ Osmanağa Mahallesi, Mürver Çiçeği Sokak, No:14/8 Kadıköy - ÍSTANBUL / TÜRKIYE 34714 Kadıköy - ISTANBUL / TURKEY 34714 e-posta: editor@rumelide.com e-mail: editor@rumelide.com, tel: +90 505 7958124, +90 2167730616 phone: +90 505 7958124, +90 2167730616
} 


\section{Araştırmanın önemi}

Sahadaki çalışmalara bakıldığında teknolojinin ya da akran öğretiminin konuşma kaygısı üzerindeki etkilerine yönelik bazı çalışmalar bulunmakla birlikte (Merikoski, 2006; Kara, Şahin, Kapat, 2020, Sallabaş, 2012,) hem teknolojinin hem de akran öğretiminin birlikte kullanıldığı öğretim modellerinde bu durumun konuşma kaygısı üzerinde ne gibi etkileri olduğuna ilişkin tam bir veriye rastlanılamamıştır. Her ne kadar Maltepe ve Bayrakdar'ın (2021) yabancı dil olarak Türkçe öğretiminde akran değerlendirmenin konuşma becerisine etkisi araştırılmışsa da söz konusu çalışma hem konuşma kaygısı ile doğrudan ilintili değildir hem de çalışmada akran öğretimi süreci teknoloji destekli olarak gerçekleştirilmemiştir. Dolayısıyla bu çalışma, teknoloji destekli akran öğretiminin konuşma kaygısı üzerindeki etkileri göstermesi bakımından önemlidir.

\section{Araştırmanın amacı}

Çalışma, yabancı dil olarak Türkçe öğrenen bireylerin ana dili konuşuru olan akranları ile teknoloji destekli etkileşime girmelerinin konuşma kaygılarına etkisini araştırmayı hedeflemektedir. $\mathrm{Bu}$ çalışmanın amacı, -pandemik bir dönemi de yaşadığımız bir süreçte- hem teknolojinin imkanlarından faydalanıp hem de akran öğretiminin avantajlarını kullanarak yapılacak uygulamaların Türkçe öğrenen yabancıların konuşma kaygılarını azaltıp azaltamayacağını ya da bu olguların konuşma kaygısı üzerinde ne oranda etkileri olacağını ortaya koymaktır. Bu bağlamda çalışmanın temel sorusu; "Teknoloji destekli akran öğretiminin yabancı dil olarak Türkçe Öğretimi sınıflarında yaşanan konuşma kaygısı üzerindeki bir etkisi var mıdır?” şeklindedir.

\section{Konuşma kaygısı}

Bireyin sözlü iletişim sürecinde huzursuz ve tedirgin olma durumu olarak tanımlanan Iiletişim kaygısının temel nedenleri arasında utangaçlık, sessizlik ya da isteksizlik gibi kişilik özellikleri bulunmaktadır (Ülper, Çetinkaya 2019). Yabancı dil olarak türkçe öğretiminde beceri alanlarının öğretimi önemli bir yer tutar. Konuşma becerisi bağlamında yaşanılan "konuşma kaygısı" ise Türkçe öğrenicilerinin dil becerileri bağlamında karşı karşıya kaldıkları en önemli engellerden biri olarak görülmektedir. Nitekim Krashen'in "Duygusal filtre hipotezi”ne göre her ne kadar anlamlı girdiler dil öğrencisinin başarısını olumlu yönde etkilese de olumsuz duygular ile tutumlardan ve kaygılardan oluşan duygusal filtre, öğrencinin dili öğrenmesinin önünde yıkılması gereken bir bariyeri oluşturur.

Dil kaygısının kaynaklarına bakıldığında ise üç önemli kaynağın öne çıtığı görülmektedir. :

- İletişim kaygısı,

- Olumsuz değerlendirilme korkusu ve

- Sinav kaygisidir.

Yabancı dil kaygısıyla ilgili çalışmalar, en çok yabancı dil sınıflarındaki konuşmalarda kaygının ortaya çıkktı̆̆ını göstermektedir (Bekleyen'den akt. Sallabaş, 2012, 2202). Nitekim MacIntyre ve Gardner da $(1995,93)$ konuşma alıştırmalarının kaygıyı artırdığını çünkü konuşma esnasında, yabancı dil öğrenen insanların diğer insanlarla iletişim kurmak zorunda olduklarını belirtmişlerdir (Öner ve Gedikoğlu'ndan akt. Sallabaş 2012, 2202).

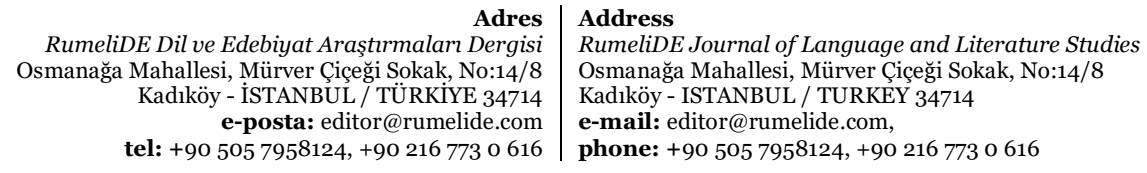


The effect of technology supported peer teaching on speaking anxiety in teaching Turkish as a foreign language / B. İnce (pp. 171-179)

\section{Akran öğretimi}

Yabancı dil olarak Türkçe öğretiminde akran öğretimi Türkçeyi yabancı dil olarak öğrenen öğrencilere ana dili Türkçe olan bireylerin yardım etmesi, Türkçe bağlamında ana dili konuşurlarının bilgi ve tecrübelerini yabancı öğrencilere aktarması biçiminde uygulanan bir öğretim yöntemi olarak tanımlamak mümkündür. Bu süreç çoğu zaman öğretmen gözetiminde gerçekleşir. Konu hakkında bilgi sahibi olan öğrencinin, aynı sınıf düzeyindeki sosyal becerileri düşük diğer bir öğrenciye ya da öğrencilere bir kavramı ya da bir beceriyi öğretmesi şeklinde gerçekleşir. Akran öğrenmesinde; süreç, her öğrencinin, öğrenme hızına, algılama düzeyine ve öğrenme biçimine göre şekillenebilir. Süreç sırasında geri bildirim ve revize anında gerçekleşebilir. Öğrenme süreci her öğrenci için en uygun şekilde ilerlediği için hedefe ulaşmak çok daha kolaydır. Öğretici pozisyondaki öğrenciler ise akademik anlamda kendilerini geliştirme ve sosyal olgunluğa erişme olanağı bulurlar. İletişim, eleştirel düşünme becerileri, analiz yeteneği ve çalışma alışkanlıklarını geliştirme firsatı yakalarlar. Koç, akran öğretiminin faydalarını şu şekilde şemalandırmıştır (Koç; 2020, 29):

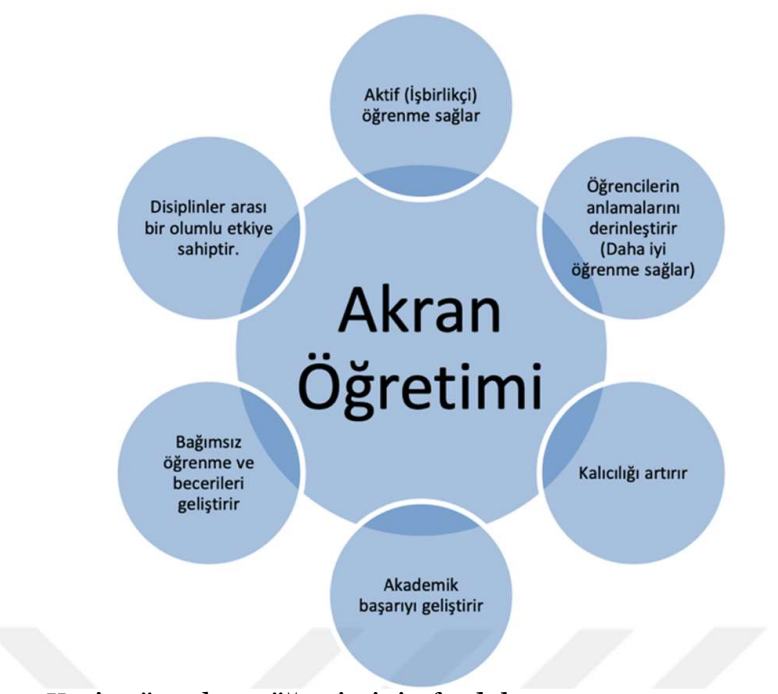

Şema1: Koç’a göre akran öğretiminin faydaları

Akran öğretimi süreci beş basamaktan oluşmaktadır. Demirel, akran öğretiminin bu basamaklarını şöyle açılamaktadır (Demirel, 2003 akt. Koç, 2020: 26):

1. Akran gruplarının belirlenmesi

2. Öğretici rolünde olan öğrencilere gerekli bilgilendirmelerin yapılması,

3. Öğretmen tarafından hazırlanan materyallerin nasıl kullanılacağı ile ilgili

eğitimlerin verilmesi,

4. Akran gruplarının plana uygun bir şekilde çalışması,

5. Süreç içerisinde öğretmenin grup çalışmalarını takibi ve rehberliği.

\section{Yabancı dil olarak Türkçe öğretiminde teknoloji kullanımı}

Teknoloji tabanlı öğrenme modelleri hızla artmakta ve eğitim süreçleri içşindeki işlevleri de giderek daha etkili bir hal almaktadır. Nitekim Durmuş'a göre de teknolojik araçların insan hayatındaki yeri ve işlevleri bu derecede hızlı bir biçimde artarken, dil öğretim faaliyetlerinin bu araçlardan etkin bir

\footnotetext{
RumeliDE Dil ve Edebiyat Arastrmalar Adres $\mid$ Address

RumeliDE Dil ve Edebiyat Araşttrmaları Dergisi $\quad$ RumeliDE Journal of Language and Literature Studies Osmanağa Mahallesi, Mürver Çiçeği Sokak, No:14/8 Osmanağa Mahallesi, Mürver Çiçeği Sokak, No:14/8 Kadıköy - ISTANBUL / TÜRKIYE 34714 Kadıköy - ISTANBUL / TURKEY 34714 e-posta: editor@rumelide.com e-mail: editor@rumelide.com, tel: +90 505 7958124, +90 2167730616 phone: +90 505 7958124, +90 2167730616
} 
biçimde yararlanmaması söz konusu olamaz (Durmuş, 2019, 101). Pandemi öncesinde öğreniciler ve öğreticiler açısından önemli bir avantaj yaratan ve çoğu zaman tercih nedeni olan dil öğretiminde teknoloji kullanımı, Pandemi ile birlikte artık kaçınılmaz bir süreç haline gelmiştir. Yabancı dil öğretiminde teknoloji tabanlı modellerin öğrenci motivasyonunu artırdığına ve dil becerilerindeki performanslarını da olumlu yönde etkilediğine ilişkin çok sayıda çalışma bulunmaktadır.

Arslan ve Adem (2010) tarafından yapılan araştırmada yabancılara Türkçe öğretiminin bilgisayar destekli ders materyallerinden yararlanılmasının öğrenme motivasyonunu arttırmaya katkı sağladığı vurgu yapılmıştır.

Benzer şekilde Geçgel ve Peker de (2020) Teknoloji kullanımının başta konuşma olmak üzere tüm beceri alanlarında dil performansları üzerinde olumlu etkileri olduğunu söylemektedir.

Eğitim teknolojilerindeki hızlı değişim, gerekli alt yapının bulunması ve öğreticilerin bu alt yapıyı optimum düzeyde kullanmaları halinde büyük bir avantaj oluşturabilir. Ayrıca pandemik bir döneme girdiğimiz de düşünüssecek olursa eğitim teknolojilerinden yararlanmanın bir tercih değil aksine bir zorunluluk olduğunu da belirtmek gerekir.

\section{Yöntem}

Bu çalışmada "Eylem odaklı yaklaşımı" temele alan bir uygulama planlanmıştır ve "Görev odaklı bir çalışma” olduğu söylenebilir. Coşkun'un Ellis’ten (2003) aktardığına göre görev kavramının bazı özellikleri şöyle ifade edilebilir (Coşkun, 2017: 93-94):

1. Görev kavramı, bir çalışma planıdır (öğrenci çalışma planı).

2. Görev kavramı, mana üzerine vurgu yapar.

3. Görev kavramı, dili günlük hayatta olduğu gibi kullanmayı içerir.

4. Görev kavramı dört dil becerisinden birini ya da birkaçını içerebilir.

5. Görev kavramı, bir görevi tamamlamak için bilginin seçimi, sınıflandırılması ve değerlendirilmesi gibi bilişsel süreçleri içerir.

6. Görev kavramının açıkça tanımlanmış iletişimsel amacı/sonucu vardır

Tarama modelinde yapılan betimsel nitelikli bu çalışmada veri toplama tekniklerinden sormaca tekniği kullanılmıştır. Bu bağlamda Ülper ve Çetinkaya'nın (2019) "Yabancı dilde konuşma kaygısı kaynakları: B1 düzeyinde Türkçe öğrenenler üzerine bir inceleme” başlıklı çalışmalarındaki konuşma kaygısı kaynaklarından kısmen yararlanılarak 10 soruluk 5'li likert tipinde bir sormaca hazırlanmıştır. Ayrıca kısa bir «görüşme» ile de teknoloji destekli bu uygulamaya yönelik öğrencilerin görüşleri alınmıştır. Verilerin analizinde hem içerik analizi yapılmış hem de SPSS istatistik programı aracıllğıyla frekans ve yüzdeden yararlanılmıştır. Amaçsal örnekleme alt yöntemlerinden benzeşik örnekleme ile farklı sınıflarda eğitim gören 56 denek çalışmanın grubunu oluşturmaktadır. Grubun 30’u erkek 26'sı kız öğrencilerden oluşmaktadır. Grup üyeleri 8 farklı ülkeden gelerek Türkçe öğrenmekte olan kişilerden oluşmaktadır.

\section{Çalışmanın uygulanması}

Çalışmanın uygulanmasında "Google doodle"dan yararlanılmıştır. Doodle, "easy scheduling" yani kolay planlama olarak tanımlanan bir uygulamadır. Doodle ile birçok kişinin katılacağı

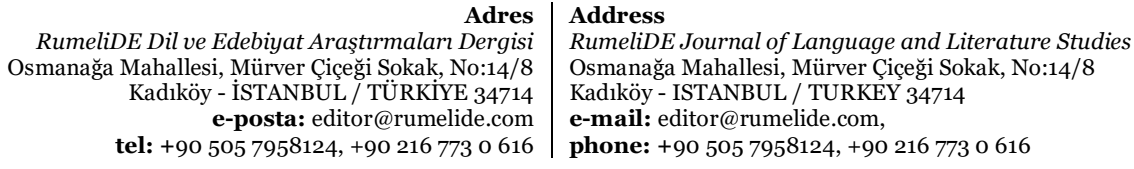


etkinlikler, toplantılar, buluşmalar kolaylıkla planlanabilmektedir. Doodle üzerinden randevulaşan Sakarya Üniversitesi TÖMER öğrencileri ile aynı Üniversitenin 2017-2018 eğitim öğretim yılında "Yabancı dil olarak Türkçe öğretimi” dersini alan 3.sınıf öğrencileri “Google Hangouts” isimli görüntülü görüşme programı üzerinden daha önceden belirlenen görevler kapsamında bir araya gelmiştir. Görüşme öncesinde hem TÖMER öğrencilerine hem de Türkçe öğretmeni adaylarına kullanacakları programlar ve yerine getirilecekleri görevler konusunda bilgi verilmiştir. Göreve konu konuşma başlıkları CEFR'te var olan B1 seviyesindeki şu başlıklardan oluşmaktadır:

- Tanışma

- $\quad$ Spor

- Kültür

- Boş zaman aktiviteleri (seyahat vb.)

- $\quad$ Kitap- Müzik- Sinema

CEFR'e göre B1 seviyesindeki öğrenciler aile, hobi, iş, yolculuk ve güncel olaylar gibi konularda hazırlık yapmadan konuşmalara katılabilir, deneyimlerini, hayallerini, umutlarını, isteklerini ve olayları betimlemek için çeşitli dilsel kalıpları yalın bir şekilde birbirine bağlayabilirler. Bir öyküyü anlatabilir, bir kitap ya da filmin konusunu aktarabilir ve izlenimlerini belirtebilirler. (CEFR, 2018)

Tömer'de B1 seviyesinde okuyan 56 öğrenci ile Yabancı dil olarak Türkçe öğretimi dersini alan 56 Türkçe Öğretmeni adayı doodle ile randevulaşarak Google Hangouts ile her oturumda en az 20-30 dakika olacak şekilde 5 hafta boyunca toplamda 5-7 kez karşlıklı görüşme yapmışlardır. Çalışma kapsamında kendilerine verilen performans görevlerini (karşılıklı konuşma) yerine getiren öğreniciler aynı zamanda sözcük dağarcıklarını zenginleştirme, dilbilgisi kurallarını uygulama ve akıcılık gibi kaygı kaynağı oluşturabilecek alanlarda da Türkçe öğretmeni adaylarından destek almışlardır.

\section{Bulgular ve yorum}

Çalışmanın ilk bulgusu öğrenicilerin teknoloji destekli akran öğretimine yönelik görüşlerinden oluşmaktadır. Bu görüşelere bakıldığında katılımcıların;

- \%69’u teknoloji destekli bu çalışmayı benimsediklerini ve çok beğendiklerini,

- \%15'si teknoloji destekli bu çalışmayı benimsediklerini ve beğendiklerini

- \%6'sı teknoloji destekli bu çalışmayı çok benimsemediklerini ve kendilerini etkilemediğini

- \%10’u ise teknoloji destekli bu çalışmaya ilişkin düşüncelerini «kararsızım» şeklinde ifade etmiştir

Çalışmanın ikinci bulgusu; konuşmada kaygıya temel oluşturan unsurlarla ilgilidir. Söz konusu unsurlar alan yazın taraması ile belirlenmiştir. Katılımcıların büyük bir kısmı aşağıda belirtilen başlıklarda daha önce yoğun olarak yaşadıkları kaygılarda nispi azalma olduğunu ifade etmişlerdir. Çalışma grubunun 5'li likert tipinde hazırlanan 10 soruluk sormacaya verdiği cevaplar SPSS 16.00 paket programı ile kullanılarak frekans ve yüzde biçiminde analiz edilmiştir. Ortalama puanlar yorumlanırken o,80'e göre aralıklar belirlenmiştir (Balcı, 2005). Buna göre

- 1-1,79 aralığı "kesinlikle katılmıyorum";

- 1,80-2,59 aralığ "katılmıyorum";

- 2,60-3,39 aralığı "kararsızım";

RumeliDE Dil ve Edebiyat Araştırmaları Dergisi Osmanağa Mahallesi, Mürver Çiçeği Sokak, No:14/8 Kadıköy - ISTANBUL / TÜRKIYE 34714 e-posta: editor@rumelide.com tel: +90 505 7958124, +90 2167730616

Address

RumeliDE Journal of Language and Literature Studies Osmanağa Mahallesi, Mürver Çiçeği Sokak, No:14/8

Kadıköy - ISTANBUL / TURKEY 34714

e-mail: editor@rumelide.com,

phone: +90 $5057958124,+90216773$ o 616 
- 3,40-4,19 aralığı "katıllyorum"

- 4,20-5,00 aralı̆̆ı "kesinlikle katılıyorum" biçiminde yorumlanmıştır.

\begin{tabular}{|l|l|l|}
\hline Kaygı kaynakları & $\mathbf{x}$-(Ort.) & Ss \\
\hline Akıcılık & 4,40 &, 67426 \\
\hline Dilbilgisi eksikliği & 3.90 &, 69486 \\
\hline Sinırlı sözcük & 3.90 &, 87416 \\
\hline Uygulama eksikliği (Pratik) & 3.41 &, 67426 \\
\hline Hata yapma korkusu & 2.88 &, 96426 \\
\hline Özgüven & 2.64 &, 88401 \\
\hline Telaffuz & 2.36 &, 67456 \\
\hline Yetkin hissetmeme & 2,55 &, 99912 \\
\hline Olumsuz tepki görme korkusu & 2.41 &, 78954 \\
\hline $\begin{array}{l}\text { Kendini istediği/hissettiği gibi ifade } \\
\text { edememe }\end{array}$ & 2.18 &, 86754 \\
\hline
\end{tabular}

Tablo 1 : Çalışmaya katılan öğrencilerin konuşma kaygısındaki azalma durumları.

Sormacada yer alan 10 madde içinde öğrenciler; en çok akıcılık, dil bilgisi eksikliği ve sınırlı sözcük bağlamında çalışmadan önce yaşadıkları kaygılarda kayda değer bir azalma olduğunu ifade etmişlerdir. Özellikle akıcılık bağlamında yaşadıkları kaygının azaldığını belirten öğrenciler dilbilgsi eksikliğinden ve sınırlı sözcük bilmekten ve uygulama eksikliğinden kaynaklı kaygılarında da önemli bir azalma hissettiklerini dile getirmişlerdir. Öte yandan öğrenciler; hata yapma korkusu ve özgüv enden kaynaklı konuşma kaygılarının azalıp azalmadığı konusunda halen bir kararasızlık durumunu yaşadaıklarını ifade etmektedir. Bunun çalışmanın sıklı̆̆ı ile alakası olabilir. Krashen’in yoğun girdiye maruz kalma prensibi doğrultusunda çalışmanın yoğunluğunu artırmak öğrenicilerin kararsız kaldıkları bu kaygı kaynaklarına da olumlu etki yaratabilir. Ayrıca öğrenicilerin çalışmanın olumlu etkilerine rağmen telaffuzdan, kendini yetkin hissetmemekten, olumsuz tepki görme korkusundan ve kendini istediği gibi ifade edememeden kaynaklı kaygılarında belli oranlarda bir düşme meydana gelmemiştir. Ancak bununla birlikte içerik analizi ile değerlendirdiğimiz görüşme verilerinde Türkçe öğrenen yabanclların çalışmaya ilişkin görüşlerinde bu yönde olumlu izlere de rastlanılmaktadır. Söz gelimi 03-16-24-43 numaralı denekler çalışmaya ilişkin görüşlerini belirtirken kendilerini ifade etmede ya da olumsuz tepki görmede kaygı durumlarının en aza indiğini ifade etmişlerdir:

Do3: ...onlar da insan. Bizi anlarlar biliyorum. Olumsuz tepki hiç vermediler. Bu beni mutlu etti.

D16: ...Yoo hiç sıkılmadım. İstediğimi söyledim... bazen söylemedim ama söylemek için çahş̧ım. Sikılmadım.

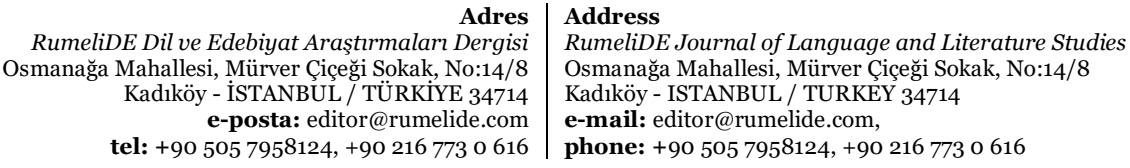

RumeliDE Dil ve Edebiyat Araştırmaları Dergis tel: +90 $5057958124,+902167730616$

nail: editor@rumelide.com

phone: +90 505 7958124, +90 2167730616 
D24: ...düşüncelerimi duygularımı anlattım. İyi hissettim kendimi. Olumsuz bir tepki olmadı bana düşüncelerim için.

D43: ...Böyle tahmin etmedim... iyi konuştum. Hoca da dinledi beni. Teşekkür ederim onlara.

Katılımcıların çalışmaya ilişkin görüşleri incelendiğinde teknoloji destekli akran öğretiminin yabancı dil öğrenicilerinin kaygı durumlarını en aza indirgediği gözlenmektedir. Özellikle çevreden olumsuz tepki alma kaygısı, özgüven, motivasyon ve öz duygu durumu bağlamında öğreniciler pozitif dönütler vermişlerdir.

\section{Sonuç ve öneriler}

Eğitim teknolojileri destekli akran öğretimi Türkçeyi yabancı dil olarak öğrenen bireylerin konuşma kaygılarının bazıları üzerinde olumlu etkiler yaratmaktadır. Bazı konuşma kaygısı kaynaklarında aynı olumlu etkiler tam olarak görülmemekle birlikte bu durum çalışmanın kısalığından ya da yoğun girdi olmamasından kayanaklı oalbilir dolayısıyla ileride benzer çalışmaları daha uzun soluklu planlamanın konuşma kaygılarını azaltmadaki durumunu daha net ortaya çıaracaktır. Bu bağlamda Türkçe öğrenen bireylerin konuşma pratiği yapmalarına yönelik İOS ve Android tabanlı uygulamalar da hazırlanmalı ve mobil öğrenme platformlarının sayıları artırılmalıdır. Başta Türkçe Öğretmenliği bölümleri (Ana bilim dalları) olmak üzere TÖMER öğrencileri ile üniversitede okuyan Türk öğrencileri arasında akran öğetimine yönelik formal-informal- (ya da non-formal) öğrenim modelleri üzerinde daha çok durulmalıdır.

\section{Kaynaklar}

Arslan, M. ve Adem, E. (2010). Yabancılara Türkçe öğretiminde görsel ve işitsel araçların etkin kullanımı. Dil Dergisi, 147, 63-86.

Balcı A. (2005). Sosyal bilimlerde araştırma yöntem teknik ve ilkeler (5. Baskı). Ankara: Pegema.

Bayrakdar, E., \& Maltepe, S. Yabancı Dil Olarak Türkçe Öğretiminde Akran Değerlendirmenin Konuşma Becerisine Etkisi. Aydın Tömer Dil Dergisi, 6(1), 1-23.

Bekleyen, N., "Foreign Language Anxiety”, Çukurova Üniversitesi Sosyal Bilimler Enstitüsü Dergisi, s: 13(2) , (2004), s. 27-39.

Coşkun, O. (2017). Yabancı dil öğretiminde eylem odaklı yaklaşım. Dil ve Edebiyat Araştırmaları, 16(16), 83-101.

Çetinkaya, G., Ülper, H. (2019). Yabancı dilde konuşma kaygısı kaynakları: Bı düzeyinde Türkçe öğrenenler üzerine bir inceleme.

Durmuş, M. (2019). Dil öğretiminde öğretici yeterlilikleri ve pedagojik muhakeme becerisi. Ankara: Grafiker.

Demirci, N. ve Şekercioğlu, A. G. (2009). Akran öğretimi yönteminin üniversite öğrencilerinin elektrostatik konusundaki başarılarına etkisi ve yönelimi. E journal of New World Science Academy, 4 (1). 37-51.

Ergür, D. O., "Yabancı Dil Öğrenimi Sürecinde Kaygı", Hacettepe Üniversitesi Eğitim Fakültesi Dergisi, s: 26 (2004), s. 48-53.

Geçgel, H., Peker, B. Multimedya araçlarının yabancı dil öğretimine etkisi üzerine öğretmen görüşleri. RumeliDE Dil ve Edebiyat Araştırmaları Dergisi, (20), 12-22

Kara, M., Şahin, S., Kapat, S. Yabancı Uyruklu Öğrencilerin Türkçe Öğrenme Sürecinde Akran Öğretiminin Etkisi: Deneysel Bir Çalışma. OPUS Uluslararası Toplum Araştırmaları Dergisi, 16(Eğitim ve Toplum Özel sayısı), 5974-5994.

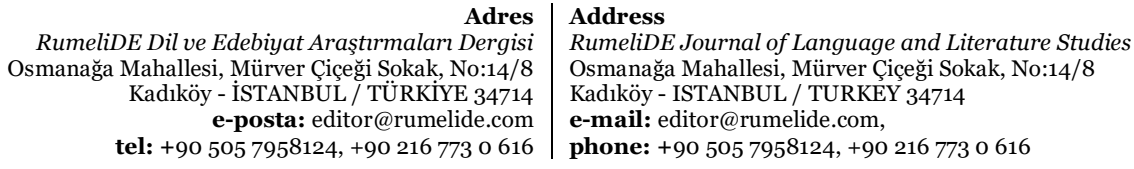


Koç, A. (2020). Bulut tabanlı akran öğretiminin öğretmen adaylarının akademik başarı, iletişim becerileri ve derse ilişkin tutumlarına etkisi. İnönü Üniversitesi EBE. Yayınlanmamış Yüksek lisans tezi. Malatya.

Merikoski, H. L. (2006). Une Étude sur l'usage de l'Internet dans l'enseignement du FLE-la parole des étudiants (Master's thesis).

Öner, G. ve Gedikoğlu, T., “Ortaöğretim Öğrencilerinin İngilizce Öğrenimlerini Etkileyen Yabancı Dil Kaygısı”, Gaziantep Üniversitesi Sosyal Bilimler Dergisi, s: 6(2) (2007), s. 144-155.

Sallabaş, M. E. (2012). Türkçeyi yabancı dil olarak öğrenenlerin konuşma kaygılarının değerlendirilmesi. Electronic Turkish Studies, 7(3).

Şeref, İ. (2018) Yabancı Dil Olarak Türkçe Öğretiminde Akran Öğretimi Modeli ed: Şahin, A. "Yabancı Dil Olarak Türkçe Öğretimi/Kuramlar, Yaklaşımlar, Etkinlıkler”, Pegem yay. Ankara.

Adres
RumeliDE Dil ve Edebiyat Araşturmaları Dergisi Osmanağa Mahallesi, Mürver Çiçeği Sokak, No:14/8 Kadıköy - İSTANBUL / TÜRKIYE 34714 e-posta: editor@rumelide.com tel: +90 $5057958124,+902167730616$
Address

RumeliDE Journal of Language and Literature Studies Osmanağa Mahallesi, Mürver Çiçeği Sokak, No:14/8

Kadıköy - ISTANBUL / TURKEY 34714

e-mail: editor@rumelide.com,

phone: +90 505 7958124, +90 2167730616 